\title{
Updated consensus statement on biological agents, specifically tumour necrosis factor $\alpha$ (TNF $\alpha$ ) blocking agents and interleukin-1 receptor antagonist (IL-1 ra), for the treatment of rheumatic diseases, 2004
}

\author{
D E Furst, F C Breedveld, J R Kalden, J S Smolen, G R Burmester, J W J Bïlsma, M Dougados, \\ P Emery, E C Keystone, L Klareskog, P J Mease
}

Ann Rheum Dis 2004;63(Suppl II):ii2-ii12. doi: 10.1136/ard.2004.029272

A $s$ in previous years, the consensus group to consider the use of biological agents was constituted by rheumatologists from the Universities of Erlangen, Leiden, and Vienna in Europe in cooperation with other Universities in the USA, Canada, and Europe. Pharmaceutical industry support was obtained from a number of companies, but these institutions had no part in the decisions about the specific programme or about the academic participants at this conference.

The perspective of this consensus is from the treating physician's point of view.

The 128 rheumatologists and bioscientists who attended the consensus conference were chosen from a worldwide group of physicians and other scientists from 20 countries with expertise in the use of biological agents for the treatment of rheumatic diseases. The number of attendees and participants were limited so that not everyone who might have been interested could be invited.

Additional information has come to light in the past year, corroborating the major positive effect these drugs have had in rheumatoid arthritis (RA) and other rheumatic diseases, as well as further documenting adverse events. Therefore an update of the previous consensus statement ${ }^{1}$ is appropriate. The consensus statement is annotated to document the credibility of the data supporting it as much as possible. This annotation is that of Shekelle et $a l^{2}$ and is described in appendix 3. As the number of possible references has become so large, sometimes reviews were used and, if they contained category A references, will be referred to as category A evidence. All participants reviewed relevant clinical published articles relating to tumour necrosis factor (TNF) and interleukin (IL)- 1 blocking agents. They were given a draft consensus statement and were asked to revise the document in small discussion groups; open discussion of the revisions led to a final document, representing this updated consensus statement.

\section{GENERAL STATEMENTS}

Individual patients differ in the aggressiveness of their disease and its concomitant structural damage, the effect of their disease on their quality of life, and the symptoms and signs engendered by their disease. They also differ in their susceptibility to, and expression of, side effects to drugs. All these factors must be examined when considering biological treatment for the patient, as must the toxicity of previous and/or alternative disease modifying antirheumatic drug (DMARD) use.

In general, in RA, when measuring response to therapy or when following patients over time, the American College of Rheumatology (ACR) response criteria (as a combined index) should not be used in a clinical practice setting to monitor individual response, although some validated measures of response (such as those which follow) should be employed (category B evidence). ${ }^{3}$ Validated quantitative measures such as Disease Activity Score (DAS), Simple Disease Activity Index (SDAI), Health Assessment Questionnaire disability index (HAQ-DI), visual analogue scales (VAS), or Likert scales of global response or pain by the patient or global response by the physician, other validated measures of pain for individual patient care, joint tenderness and/or swelling counts, and laboratory data all may be used and may be the most appropriate measures for individual patients (category B evidence). ${ }^{3}{ }^{4}$ The physician should evaluate the patient's response using the above measures to determine the patient's status and improvement.

For psoriatic arthritis (PsA), measures of response such as joint tenderness and swelling, global and pain response measures, functional indices, and acute phase reactants have been used and appear responsive (category A evidence). ${ }^{5}$ They remain, however, to be fully validated in this disease.

For ankylosing spondylitis (AS), measures such as the Bath Ankylosing Spondylitis Disease Activity Index (BASDAI) and Bath Ankylosing Spondylitis Functional Index (BASFI) have been used in a clinical trial setting but have not been validated for the routine clinical practice setting. Measures such as joint tenderness and swelling, spinal motion, global and pain response measures, functional indices, and acute phase reactants have been used and appear responsive (category A evidence). ${ }^{6-10}$ They remain, however, to be fully validated in this disease.

The use of biological agents will require physicians experienced in the diagnosis, treatment and assessment of RA and other rheumatic diseases. These physicians will need to make long term observations for efficacy and toxicity. Because these agents are not free of toxicity, patients or their representatives should be provided with information about potential risks and benefits so that they may give informed consent for treatment.

Abbreviations: aCL, anticardiolipin antibodies; $A C R$, American College of Rheumatology; ANA, antinuclear antibodies; AS, ankylosing spondylitis; CHF, congestive heart failure; DAS, Disease Activity Score; DMARD, disease modifying antirheumatic drug; EULAR, European League Against Rheumatism; HAQ-DI, Health Assessment Questionnaire disability index; IL-1 ra, interleukin-1 receptor antagonist; MTX, methotrexate; NHL, Non-Hodgkin's lymphoma; PsA, psoriatic arthritis; RA, rheumatoid arthritis; RCT, randomised controlled trial; SDAl, Simple Disease Activity Index; TNF, tumour necrosis factor; VAS, visual analogue scale 


\section{TNF BLOCKING AGENTS}

TNF blocking agents differ in composition, precise mechanisms of action, pharmacokinetics, biopharmaceutical properties, etc, but this document emphasises areas of commonality. Data which clearly have differentiated compounds will be discussed if such areas can be identified.

\section{Indications}

\section{Rheumatoid arthritis}

TNF blockers are recommended for the treatment of active RA, generally after an adequate trial of another effective DMARD, of which methotrexate (MTX) is a commonly used example. They have also been used successfully with other DMARDs (category A evidence ${ }^{11-37}$ ). TNF blocking agents can be added to pre-existing therapy, or, when appropriate, may replace previous DMARDs (category A evidence ${ }^{11-37}$ ). There is evidence that TNF blockers are effective for the treatment of RA in MTX naive patients (category A evidence ${ }^{12} 14161920$ $23-252932333637$; category D evidence ${ }^{21} 27$ ). The use of TNF blocking agents as the first DMARD for the treatment of RA (category A evidence $e^{11-14} 161920232529$ 33 36-38; category D evidence $^{3637}$ ) should, at present, be limited because one must consider emerging data on long term safety and effectiveness as well as their expense and one needs to include health economic considerations along with these other factors. However, as some patients had not yet received other DMARDs in trials of TNF blockers, TNF blocking agents may be considered as the initial DMARD in some patients (category A evidence ${ }^{14} 161920262832333637$; category D evidence $\left.^{21}\right)$.

Adalimumab and etanercept are both approved as monotherapy for RA, while infliximab is approved for use with MTX in RA. However, the cumulative weight of the evidence from several randomised controlled trials (RCTs) suggests that the combination of a TNF blocking agent and MTX yields superior results for RA when compared with monotherapy, particularly with respect to excellent clinical responses (ACR 70, EULAR remission) and radiological outcomes (category A evidence ${ }^{16} 2529333739$ ). TNF $\alpha$ blocking agents have been used with combinations of background DMARDs (category B evidence ${ }^{22}$ ).

\section{Psoriatic arthritis}

Etanercept has been approved in the USA and Europe for the treatment of PsA while adalimumab and infliximab are being tested prior to submission for review (category A, B, C evidence $^{16{ }^{40-47}}$ ). Controlled trial data to support conventional DMARDs as first line therapy for PsA are scant, showing modest effects of drugs such as MTX, sulfasalazine, and ciclosporin A on joint and skin disease in PsA (category A evidence $^{48-52}$ ). Controlled trials with etanercept (category A evidence $^{43}{ }^{4453}$ ) and infliximab ${ }^{42} 45$ have demonstrated statistically significant improvement in a number of response measures. These agents are of benefit both as monotherapy and as add-on therapy to other DMARDs such as MTX (category A evidence $e^{40-47} 53-55$ ). The skin lesions of psoriasis in patients with PsA have also improved (category A, D evidence ${ }^{55-58}$ ). No dose ranging studies of TNF blocking agents for PsA have been published.

\section{Ankylosing spondylitis}

Etanercept has been approved for the treatment of severe, active AS in Europe and the USA and infliximab is approved for this indication in Europe (category A, C evidence ${ }^{6-10}$ 59-63). Adalimumab is being tested in this disease (unpublished). In these clinical trials, TNF blocking agents were used as monotherapy and, in some trials, second line agents such as sulfasalazine or MTX were allowed as concomitant medications (category A, C evidence ${ }^{6-1059-63}$ ). The
Assessment in Ankylosing Spondylitis (ASAS) working group has published recommendations for the use of TNF blocking agents in AS (category A evidence ${ }^{64}$ ). The approved dose of infliximab in AS is $5 \mathrm{mg} / \mathrm{kg}$ every six to eight weeks after induction and the etanercept dose is the same as that used for RA (see respective package insert for each drug). No dose ranging study has been done with either drug in this indication.

Health economic data and long term safety data may change the circumstances when TNF blocking agents will be started. The cost efficacy data to date are somewhat conflicting; this may in part be due to varying underlying assumptions and the varying sources of the analysis (category B evidence ${ }^{17}$ 65-67).

\section{Other rheumatic diseases or those with prominent rheumatic manifestations}

- Trials that demonstrated a difference from placebo or positive control:

- Etanercept has been approved for juvenile idiopathic arthritis of the polyarticular type (category A evidence $^{163168}$; FDA Summary Basis of Approval)

- Infliximab has been approved to treat luminal and fistulising Crohn's disease (category A evidence ${ }^{69}{ }^{70}$; FDA Summary Basis of Approval)

- Trials that failed to demonstrate a difference from placebo:

- Sjögren's syndrome (category B evidence ${ }^{71-73}$ )

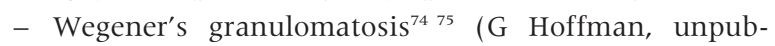
lished data)

- Anecdotal series or studies with promising results:

- See table 1

\section{Clinical use}

Efficacy

TNF blocking agents, when given using the maximum approved dosing regimens for RA, PsA, AS, and juvenile RA, should lead to significant, documentable improvement in symptoms, signs, and/or laboratory measures within 12 weeks $^{7} 8$ 11-23 25-37 40-55 5868126 (category A, B, C, D (abstract) evidence $^{6} 91060-63$ 76-78 127). There is no evidence that any one TNF blocking agent should be used before another one can be tried, just as there is no credible evidence that any one TNF blocker is more effective than any other (see above) (category A, D evidence (abstract) ${ }^{128-133}$ ). Patients have been switched from one TNF blocking agent to another but no well controlled switch trials have been published (category B, D evidence (abstract) ${ }^{128-133}$ ). These studies suggest that failure to respond to one TNF blocking agent does not preclude response to another (category $\mathrm{B}, \mathrm{D}$ evidence (abstract) ${ }^{128-133}$ ).

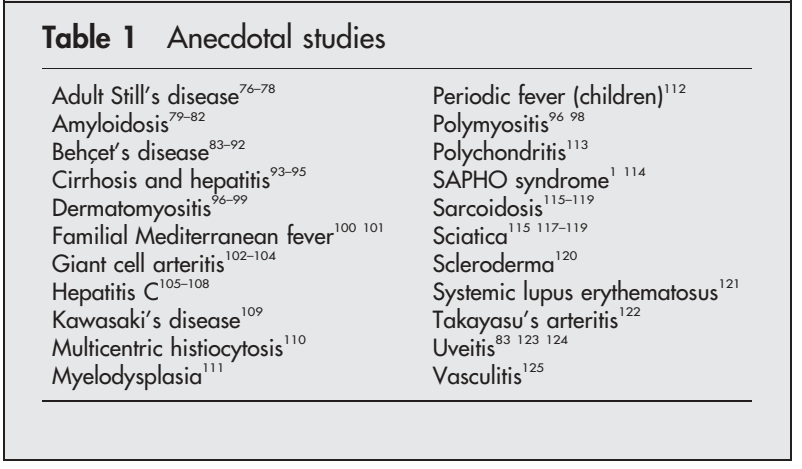


Individually important responses including patient oriented measures (for example HAQ-DI, patient's global VAS, Short Form (SF)-36) or physical measures (for example joint tenderness) should be demonstrated within 12 weeks for RA, PsA, AS and, probably, juvenile RA (category A evidence $^{6-1719-212325-3133-3740-55586368126127}$ ). If such improvement occurs, treatment should be continued. If patients show no response to these agents, they should be stopped. Observations suggest that increasing the dose or reducing the dosing intervals may provide additional benefit in RA, as may the addition or substitution of other DMARDs (category B evidence ${ }^{1133} 3437$ ). However, because regression to the mean may occur, caution is needed when interpreting apparent improvements following dose escalation in practice (category C evidence ${ }^{133}$ ).

There are data showing that TNF blocking agents slow radiographic progression in RA (category A evidence ${ }^{12} 1621$ 23-26 30126 ), and in some individuals may inhibit it (category C, D evidence ${ }^{24} 2{ }^{134}$ ). Although some patients with RA without clinical response have slowing of radiographic progression, ${ }^{30} 135$ the long term clinical implications of these changes are unknown. Until the long term implications of slowing radiological damage are clear, radiological effects alone should not determine clinical decision making.

Data show that at least one TNF blocking agent may slow the appearance of new erosions in PsA (category A evidence $\left.{ }^{43}{ }^{44}\right)$. Analyses using other as yet unvalidated radiographic measures as well, also demonstrate inhibition of radiographic damage in PsA (category A evidence ${ }^{43}{ }^{44}$ ).

\section{Warnings/adverse events Infections}

The appearance or incidence of infections in immunocompromised patients may be a surrogate for too much immunosuppression, although the drug mechanism(s) of action will help determine the specific infections that are seen.

An increased susceptibility to tuberculosis or reactivation of latent tuberculosis should be considered a class characteristic of TNF blocking agents. The clinical picture of tuberculosis may be atypical in these patients (for example miliary or extrapulmonary presentations) as has been seen in other immunocompromised patients (category $\mathrm{C}$ evidence ${ }^{136}$ ). There have been more reported cases of tuberculosis as a proportion of the total number of individuals treated in patients using infliximab and adalimumab than etanercept (category C evidence ${ }^{136}{ }^{137}$ ). This may be due in part to the fact that populations treated with the various TNF blocking agents differ and the data come from registries and voluntary reporting systems. No head to head comparisons of TNF blocking agents have been done and thus no definitive comparative data of these agents are available about the incidence of reactivation of latent tuberculosis.

Screening of patients about to start TNF blocking agents has reduced the risk of activating tuberculosis (EULAR 2003, category $\mathrm{D}$ evidence (abstract) ${ }^{138}$ ). All patients should be evaluated for the possibility of latent tuberculosis, including a history which includes evaluation for the risk of latent tuberculosis (category $\mathrm{C}$ evidence ${ }^{136}{ }^{137}$ ). This should include seeking a history of prior exposure, prior or active drug addiction, human immunodeficiency virus (HIV) infection, birth or extended living in a region of high prevalence of tuberculosis, and a history of working in a high risk tuberculosis setting such as jail, homeless shelter, drug rehabilitation centre, etc (category D evidence). In addition, physical examination and screening tests such as skin tests and chest $x$ rays should be done according to local recommendations (category C, D (abstract) evidence ${ }^{139140}$ ). Continued vigilance is required to prevent activation of latent tuberculosis or acquisition of new cases. The occurrence of opportunistic infections should also be sought.

In treating latent tuberculosis, the timeframe from after initiating antituberculous therapy to starting the TNF blocking agent remains to be determined. Experts have recommended anywhere from simultaneously starting both treatments to waiting until the completion of antituberculous therapy before beginning anti-TNF agents (category D evidence).

Opportunistic infections have occurred in the setting of TNF blocking agent use (category C evidence $\left.^{11} 151822263669^{126} 141-144\right)$. Particular vigilance is needed when considering those infections whose containment is macrophage/granuloma dependent such as listeriosis, coccidiomycosis, or histoplasmosis (category C, D evidence ${ }^{136}{ }^{137}$ ) but the incidence of opportunistic infections is extremely low (category D evidence ${ }^{136}$ ). The incidence of such infections, perhaps due to their very low incidence, has not been shown to be higher than for other DMARDs or for corticosteroids.

Serious bacterial infections have been observed in patients receiving TNF blocking agents, but it is not clear for the most part that their incidence is higher than in patients with RA using other forms of DMARD therapy and/or corticosteroids. TNF blocking agents should not be started or should be discontinued when serious infections and/or opportunistic infections occur, including septic arthritis, infected prostheses, acute abscess, osteomyelitis, sepsis, systemic fungal infections, listeriosis, etc (FDA; category C evidence $^{11} 1518222636433^{141-145}$ ). Treatment with TNF blockers in such patients should only be resumed if the infections have been treated adequately (FDA; category D evidence ${ }^{137-140}$ 147-151 (abstract) ${ }^{146}$ ).

\section{Injection site/infusion reactions}

In placebo controlled trials, injection site reactions, some of which resulted in drug discontinuation, were more common with subcutaneously administered TNF blocking agents than with placebo. Infusion reactions for TNF blocking agents given intravenously (that is, infliximab) are uncommon and are usually mild-moderate, but may, rarely, be serious (category A evidence ${ }^{12} 1316212325-28303234148$ ); (category B, C

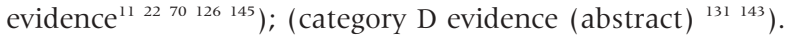

\section{Malignancies}

The incidence of lymphoma is increased in RA, particularly in RA with high disease activity (category B evidence ${ }^{152}$ ). It may also be increased in patients with AS (category D evidence). TNF blocking agents used in RA appear to be associated with an approximate doubling of the risk for non-Hodgkin's lymphomas (NHLs) relative to the risk in patients with RA (category $\mathrm{C}$ evidence ${ }^{148}{ }^{152}{ }^{153}$ ). This may be due to the application of these agents in patients with more severe and longstanding disease who have higher risk to develop lymphomas. There is thus far no evidence that TNF blocking agents are associated with an increased incidence of other malignancies or recurrence in patients who have had solid malignancies previously (category $\mathrm{D}$ evidence). Vigilance with respect to the occurrence of lymphomas and other malignancies including recurrence of solid tumours remains warranted in patients using these medications.

\section{Haematological}

A few rare instances of pancytopenia and aplastic anaemia have been reported 2633145148154 (category A, C evidence). If haematological adverse events occur, TNF blockers should be stopped and patients evaluated for evidence of other underlying disease or other causative medications before ascribing the event as potentially related to the TNF blockade. (category D evidence). 


\section{Cardiovascular}

High dose infliximab $(10 \mathrm{mg} / \mathrm{kg}$ ) appears to be associated with an increased relative risk of worsening congestive heart failure and mortality, particularly in RA patients with New York Heart Association (NYHA) class III-IV congestive heart failure (CHF) (category $\mathrm{B}, \mathrm{D}$ evidence ${ }^{148}{ }^{155}$ ). There is presently no substantive evidence that infliximab, $5 \mathrm{mg} / \mathrm{kg}$ or etanercept at $25 \mathrm{mg}$ twice a week increases the incidence of $\mathrm{CHF}$ or $\mathrm{CHF}$ related mortality in patients with functional class I CHF (category B, D evidence ${ }^{114148} 155$ ). However, it should be noted that well controlled RA studies have excluded patients with complicating illnesses, including CHF. One cohort observational study in patients with RA without overt CHF showed no increase in myocardial infarction related mortality when using TNF blocking agents. ${ }^{3}$ Each patient's risk versus benefit should be carefully considered before TNF blocking agents are begun or continued in those circumstances (FDA; category D evidence).

\section{Hepatitis}

The long term safety or efficacy of TNF blockers in patients with chronic hepatitis $\mathrm{B}$ and $\mathrm{C}$ is not known. One observational and one controlled study (the latter with interferon alfa and ribavirin background) revealed no effect on viral load and no increased incidence of adverse events; further, symptoms and liver function tests may have improved (category C evidence ${ }^{93} 95105107148156$ ). TNF blockers should not be used in patients with hepatitis $\mathrm{B}$ infection (category C evidence $^{148}$ ).

Elevations of liver function test have been observed with infliximab and etanercept, although confounding medications and circumstances make the meaning and aetiology of these elevations unclear (FDA; category C, D evidence ${ }^{11}{ }^{94}{ }^{157}$ ). The follow up and monitoring for liver function test elevations should be governed by the patient's concomitant medications, conditions, and patient related risk factors.

\section{Pregnancy}

Some patients have become pregnant while being treated with TNF blocking therapy and small, pharmacovigilance studies have not shown that rates of normal live births, miscarriages, and therapeutic terminations are different from published rates for the normal population (category D evidence (abstract $)^{158}$ ). In these patients TNF blocking agents were generally stopped when pregnancy was discovered but it is not known if this affected the outcome (category D evidence). There are insufficient data to advise continuation or starting of anti-TNF therapy if a patient becomes pregnant. It is advised that patients and physicians discuss the issue of TNF blocking therapy when pregnancy planning takes place or if pregnancy occurs during ongoing TNF blocking therapy and that this discussion is documented.

\section{Autoimmune-like syndromes}

Syndromes resembling drug induced lupus have occurred in patients receiving TNF blocking agents and treatment should be stopped if there is clinical evidence of a drug induced lupus-like syndrome. These symptoms are highly likely to resolve upon discontinuation of the TNF blocking agent (category C, D (abstract) evidence 26283370141142145 159-162). There is no evidence that patients with RA who had, or develop, positive antinuclear antibodies (ANA), anticardiolipin antibodies (aCL), and/or ds-DNA are at significantly increased risk for the development of drug induced lupus (FDA; category C, D (abstract) evidence ${ }^{11} 262833$ 141-145 148 159-163).

Instances of demyelinating-like disorders and optic neuritis have been reported in patients receiving TNF blockers, although it is not known currently if the incidence in patients receiving TNF blockers is different from a comparable group of patients with RA who have not received TNF blocking agents (category C evidence; category D evidence 2633145148154164$)$. These agents should be stopped if a demyelinating-like disorder or optic neuritis occurs. Patients with a history of definite demyelinating disease or optic neuritis should not receive TNF blocking agents (category D evidence).

\section{Issues specific to PsA}

Safety and tolerability data of anti-TNF medications in PsA did not demonstrate any adverse events that were significantly different from RA trials. However, because liver biopsy studies suggest that patients with psoriasis and PsA demonstrate a greater proclivity for hepatotoxicity with MTX therapy than patients with RA (category B evidence ${ }^{165}$ ), it is not known if the safety profile from RA trials is completely comparable with PsA.

\section{Precautionary statements}

The safety of TNF blockade is unknown or has not been established in the following situations:

(1) Chronic infections, including HIV, etc.

(2) During lactation.

(3) When IL-1 blocking agents and TNF blocking agents are used together-infections are common and serious infections have occurred. This combination should be used with great caution until new data become available (category D evidence ${ }^{144}$ ).

Other areas where knowledge is lacking are highlighted in the consensus group's recommendations for areas most urgently requiring further research.

\section{Research questions}

Among a number of potential areas requiring action and/or further research, the consensus group felt the following projects or directions were most important in each of four areas: registries, efficacy, toxicity, and general issues.

\section{Registry}

(1) Long term registries continue to be needed to monitor the toxicity of biologicals and are strongly recommended, requiring a cooperative effort among payers, government, industry, and rheumatologists.

(2) Registries of pregnancy outcomes under anti-TNF therapy (and after cessation of therapy) should be continued.

\section{Efficacy}

(1) What are the optimal dosing regimens when using TNF blocking agents?

(2) Are there predictors of response and toxicity for TNF blocking agents?

(3) Is there a correlation between radiological effect and long term effectiveness for TNF blocking agents?

(4) What are the outcomes of patients treated with TNF blocking agents where disease activity persists without joint destruction and where joint destruction is observed with little disease activity?

(5) Can biologicals be administered at lower than currently used doses and/or at dosing intervals longer than currently employed to slow or halt radiographic progression of RA in the absence of an ACR 20 response?

(6) What is the role of pharmacoeconomic evaluations to help clinicians treat individual patients? 
(7) How long do clinical and radiological benefits last in patients who stop using TNF blocking agents?

(8) Can the dose of TNF blocking agents be escalated in the event of therapeutic loss of effect?

(9) What is the effect of TNF blocking agents on growth in children with juvenile chronic arthritis?

(10) Are ACR 20/50/70, DAS, Rheumatoid Arthritis Disease Activity Index (RADAI), SDAI, the Psoriatic Arthritis Response Criteria (PsARC), and HAQ valid measures of response in PsA?

(11) What, if any, dose response exists for the use of TNF blocking agents in PsA and/or AS?

(12) Are TNF blocking agents superior to other DMARDs such as sulfasalazine or leflunomide for treating PsA and/or AS?

(13) Do TNF blocking agents modify structural damage in AS?

(14) Do patients with AS and advanced spinal fusion respond to TNF blocking agents?

(15) What are the predictors of response to TNF blocking agents in early and advanced AS and/or PsA?

Safety

(1) Can TNF blocking agents be used safely in pregnant or lactating women?

(2) What is the safety profile of TNF blocking agents during surgery? How does it compare with the safety profile of patients undergoing surgery without concomitant TNF blocker use?

(3) What duration of tuberculosis prophylaxis/treatment is necessary when patients are being treated with TNF blocking agents?

(4) Can TNF blocking agents be used in patients with a history of lymphoma and NHL or solid tumours? What is the time interval needed, before TNF $\alpha$ blockers can be used after patients with malignancies have reached a full remission?

(5) Are there differences among TNF blocking agents as regards the incidence or prevalence of opportunistic infections or other infections?

\section{Summary}

TNF blocking agents have proved to be effective DMARDs and are a major advance in the treatment of RA, PsA, AS, and juvenile chronic arthritis. Their use is expanding to other rheumatic diseases. However, rare to uncommon and unexpected toxicities have been found and others may yet be found during their use. Studies in selected areas of efficacy, toxicity, and general use of TNF blocking agents are needed to help further define the most appropriate use of these agents. Further considerations when using TNF blocking agents in this disease should balance efficacy, toxicity, and cost issues and then recognise that data in subpopulations are still being acquired. It is hoped that this statement, which is based upon the best evidence available at the time of its creation and is modified by expert opinion, will facilitate the optimal use of these agents for our patients with RA.

\section{IL-1 BLOCKING AGENTS}

To date only one IL-1 blocking agent (anakinra) has reached the market and references are therefore to this product. As other agents of this class reach the market, the document below will be changed appropriately, but it may appear somewhat inconsistent at present as an attempt is made to separate presumed class characteristics from data relating to this prototypic compound.

\section{Indications}

IL-1 blocking agents may be used for treatment of active RA, alone or with MTX (category A evidence ${ }^{32}{ }^{37}$ ). Despite this evidence, the anakinra label presently requires its use with MTX in Europe. IL-1 blocking agents are recommended for the treatment of active RA after an adequate trial of another effective DMARD, of which MTX is a common example (category D evidence). Anakinra has been used with other effective DMARDs (category D evidence ${ }^{23}$ ).

The use of IL-1 blocking agents as the first DMARD for the treatment of RA should, at present, be limited because no trials in early RA have been performed, these compounds are expensive, and one needs to include cost considerations along with those of efficacy, effectiveness, and long term safety (category D evidence).

IL- 1 receptor antagonist (IL-lra) has been used in juvenile RA, adult onset Still's disease, neonatal onset multisystem inflammatory disease, Muckle-Wells syndrome, and systemic lupus erythematosus (category C, D evidence).

\section{Clinical use}

IL-1 blocking agents can lead to significant, documentable improvement in symptoms, signs, and/or laboratory measures within 2-16 weeks (category A evidence ${ }^{32}{ }^{37}$ ). Measures of patient related outcomes such as global patient VAS or HAQ may be more sensitive to the effects of one IL-1 blocking agent (anakinra) than physical measures such as joint tenderness/swelling (category $\mathrm{D}$ evidence ${ }^{27}$ ). These measures of response should be followed and individually important responses should be demonstrated within 816 weeks (category A evidence ${ }^{32} 33$ ). If clinically important improvement occurs, treatment should be continued (category $\mathrm{D}$ evidence).

Data show that IL-1 blocking agents, of which anakinra is the marketed prototypic compound, slows radiographic progression in RA (category A evidence ${ }^{33}{ }^{37}$ ). Data are conflicting about the usefulness of IL-lra after patients have failed TNF blocking agents. One open trial showed no response while some observational data were more favourable (category D evidence). Recent data indicate that IL-1ra may be effective in treating adult onset Still's disease (category D evidence (abstract) ${ }^{166}$ ).

A dose related incidence of injection site reactions, affecting up to $70 \%$ of patients, has occurred with the use of anakinra. These reactions often do not require treatment and seem to moderate with continued use in some patients (category A evidence ${ }^{30}{ }^{32} 37$; category D evidence ${ }^{23}$ ).

There are no data to advise either termination or continuation of IL-1 blocking agents if a patient becomes pregnant.

\section{Warnings}

Severe infections have been described in patients receiving IL-lra, but it is not clear that their incidence is higher than in patients with RA using other DMARD treatments with or without corticosteroids. These compounds should not be started or should be discontinued when serious infections occur (category A evidence ${ }^{12} 30{ }^{32}{ }^{37}$ ) (category D evidence ${ }^{23}$ ). Treatment with IL-1 blocking therapy in such patients should only be resumed if the infections have been adequately treated (category D evidence). To date, there is no indication that IL-1 blocking compounds are associated with an increased incidence of tuberculosis (category D evidence).

\section{Precautionary statements}

The safety of IL-lra is unknown or has not been established in the following situations:

(1) Lymphoma, lymphoproliferative and other malignancies.

(2) During pregnancy and/or lactation. 
(3) In combination with other biologicals/targeted therapy, such as TNF blocking agents. Infections are common and serious infections have occurred when using IL-1 blocking agents and TNF blocking agents together; this combination should be used with great caution until new data become available (category $\mathrm{D}$ evidence ${ }^{25}$ ).

(4) When considering primary vaccinations or live attenuated vaccines.

Other areas where knowledge is lacking are highlighted in the consensus group's recommendations for areas most urgently requiring further research.

\section{Research questions}

Among a number of potential areas requiring action and/or further research, the consensus group felt the following projects or directions were most important in each of four areas: registries, efficacy, toxicity, and general issues.

\section{Registry}

(1) Long term registries to monitor the toxicity of biologicals are recommended, requiring a cooperative effort among payers, government, industry, and rheumatologists.

(2) Registries of pregnancy outcomes under IL-1 blocking therapy (and after cessation of therapy) should be continued.

\section{Efficacy}

(1) What is the efficacy of IL-1 blocking agents in polyarticular juvenile arthritis and other rheumatic diseases, including osteoarthritis?

(2) Do IL-1 blocking agents have an effect on pain?

\section{Toxicity}

(1) Can IL-1 blocking agents be used in patients who cannot be treated with TNF blocking agents because they have a history of tuberculosis or latent tuberculosis and cannot tolerate appropriate therapy for the latter, for some reason?

\section{Summary}

IL-1 blocking agents, of which anakinra is the prototypic and sole example, are effective for the treatment of RA but their specific place (for example, before, or after TNF blocking agents) in the rheumatological armamentarium is not yet defined. Publication of studies in selected areas of efficacy, toxicity, and general use of IL-1 blocking agents is needed to help further define the most appropriate use of these agents. Further considerations when using IL-lra in this disease must include cost issues and the recognition that data in subpopulations are still being acquired. It is hoped that this statement, which is based upon the best evidence available at this time of its creation and modified by expert opinion, will facilitate the optimal use of IL-lra for our patients with RA. IL-1 blockers appear to be highly active in some periodic fever syndromes, such as Muckle-Wells syndrome, and may be active in adult onset Still's disease.

\section{Appendix 1: Abbreviated summary of the "Updated consensus statement on biological agents for the treatment of rheumatic diseases, 2004"}

- Rheumatologists and bioscientists from many countries met to develop the consensus statement.
- The process included a review of relevant clinical published articles and, through an iterative process, the reaching of consensus.

- Individual patients differ in many aspects of their disease and may respond differently to various TNF blocking agents, so one must individualise therapy.

\section{Indications}

- TNF blockers are recommended for the treatment of active RA, PsA, AS, and juvenile chronic arthritis after using another DMARD (MTX is the most common of several DMARDs frequently used).

- TNF blocking agents can be added to pre-existing therapy or, when appropriate, may replace previous DMARDs or other biologicals.

- TNF blockers are effective in MTX naive patients.

- At present, TNF blocking agents as the first DMARD for the treatment of RA should be limited due to considerations of long term safety. Cost considerations should be included when considering the use of TNF blocking agents.

- When other DMARDs are contraindicated, TNF blockers may be considered as the first DMARD.

- Etanercept has been approved for juvenile idiopathic arthritis of the polyarticular type as well as PsA and AS.

- Infliximab is approved in Europe for AS.

- Infliximab is approved for Crohn's disease.

- Adalimumab and infliximab are being tested in PsA.

- There is no evidence that any one TNF blocking agent should be used before another or that any TNF blocker is more effective than another, although individual differences may exist between patients.

- TNF blocking agents are being evaluated in Wegener's granulomatosis, giant cell arteritis, Takayasu's arteritis, adult onset Still's disease, Sjögren's syndrome, hepatitis C, Behçet's disease, uveitis, polymyositis, dermatomyositis, systemic lupus erythematosus, systemic sclerosis, and other conditions, although more work is needed in all cases.

- Pharmacoeconomic and long term safety data may modify all of the above statements but only conflicting data have been published to date.

\section{Clinical use}

- When used in adequate doses and sufficiently frequent dosing regimens, TNF blocking agents should lead to significant, documented improvement within 12 weeks for RA, AS, PsA, and juvenile RA.

- The ACR response criteria (as a combined index) should not be used to monitor individual response, while other validated quantitative measures such as the DAS, HAQ-DI, SDAI, VAS, Likert scales, joint tenderness and/or swelling, and laboratory data may be more appropriate measures for individual patients.

- If documentable significant improvement occurs, treatment should be continued.

- If patients show no response to these agents at their maximum approved dose they should be stopped in 12 weeks.

- If an incomplete response occurs, increased doses or reduced dosing intervals may provide additional benefits, as may other DMARDs or other biologicals, although further study on this issue is required.

- TNF blocking agents slow radiographic progression in RA and may do so in PsA. Until the long term implications of 
this slowing are clear, radiological changes alone should not determine clinical decision making.

\section{Warnings}

- Tuberculosis may be reactivated in patients given any TNF blockers; numerically more reactivation of tuberculosis occurs with infliximab than etanercept, although analyses and circumstances do not permit differentiation among these drugs with respect to reactivation of latent tuberculosis. An early adalimumab study also showed more frequent tuberculosis reactivation after very high adalimumab dosing (no longer seen in later studies where tuberculosis screening was done).

- Screening for latent tuberculosis is necessary, specially in countries with high prevalence of tuberculosis.

- Individual evaluations, including history, physical examination, chest $x$ ray examination, and/or purified protein derivative test, should be done and therapy for latent tuberculosis considered according to local recommendations.

- TNF blocking agents should not be started or should be discontinued when serious infections occur.

- Opportunistic infections have occurred in the setting of TNF blocking agent use. The incidence, however, is low.

- Injection site reaction (etanercept, adalimumab) and infusion reaction (infliximab) occur more commonly in patients receiving these agents than in controls. They are usually mild-moderate.

- NHLs have occurred in patients using TNF blocking agents, and the incidence may be approximately twice that of patients given other DMARDs although it is not clear if the incidence of these tumours is increased relative to an appropriate disease control group.

- No evidence to date links TNF blocking agents with solid tumours such as breast or gastrointestinal cancers.

- A few instances of pancytopenia and aplastic anaemia have been reported although the relationship and frequency of this adverse event is not sufficiently understood to make specific recommendations about monitoring at this time.

- If pancytopenia or aplastic anaemia occurs, TNF blockers should be stopped and patients evaluated for evidence of other underlying disease.

- Severe CHF (class III-IV by NYHA criteria) represents a situation where TNF blockade needs to be used with great caution, particularly in high doses. There are no credible data in patients without CHF or with class I disease preventing the use of TNF blockers.

- The safety of TNF blocking agents to treat chronic hepatitis $\mathrm{C}$ is unknown, although some data indicate that viral load is not increased, that the incidence of adverse events is not increased, and that liver function tests may normalise. Caution in the use of these agents in hepatitis $C$ patients is, nevertheless, recommended.

- The use of TNF blocking agents in patients with hepatitis B is not recommended.

- Insufficient data are available about the use of anti-TNF therapy prior to or during pregnancy to allow advice in this circumstance. Although pharmacovigilance data have shown the same rates of normal births, miscarriages, and therapeutic terminations as in the general population, patients and physicians should discuss this issue if pregnancy occurs or is planned and this discussion should be documented.

- In the rare cases when a syndrome resembling drug induced lupus develops, TNF blocking agents should be stopped.
- The presence or development of positive ANA, aCL, and/or ds-DNA does not significantly increase the risk of developing drug induced lupus.

- Instances of demyelinating-like disorders and optic neuritis have been reported in patients receiving TNF blockers. These agents should be stopped if a demyelinating-like disorder occurs.

- Patients with a history of a definite demyelinating disease should not receive TNF blocking agents.

\section{Precautionary statements}

- The safety of TNF blockade is unknown in the following situations: chronic infections including HIV, during pregnancy, or lactation.

- When considering primary vaccinations or live attenuated vaccines caution should be exercised, although some preliminary data show no differences in response to pneumococcal vaccine relative to normal controls.

\section{Appendix 2: Abbreviated summary of the "Updated consensus statement for the use of biological agents in the treatment of rheumatoid arthritis and other rheumatic diseases - IL- 1 blocking agents subsection"}

- Rheumatologists and bioscientists from numerous countries met to develop the consensus statement.

- The process included a review of relevant clinical published articles and, through an iterative process, the reaching of consensus.

\section{Indications}

- IL-1 blocking agents may be used for the treatment of active RA, alone or with MTX. In Europe, IL-1 blocking agents (anakinra) should presently be used in conjunction with MTX.

- IL-1 blocking agents will probably be effective when used with other effective DMARDs.

\section{Clinical use}

- IL-1 blocking agents (anakinra) can lead to significant documentable improvement in symptoms, signs, and/or laboratory measures of RA within 2-16 weeks.

- Response measures should be followed and individually important responses should be demonstrated within 8-16 weeks.

- If a clinically important response to an IL-1 blocking agent occurs, the agent(s) should be continued.

- IL-1 blocking agents (anakinra) slow radiographic progression in RA.

- There are observational data that IL-1ra is effective in patients failing TNF blocking therapy.

- Injection site reactions occur in up to $70 \%$ of patients in a dose response manner. These injection site reactions often do not require treatment and may diminish with continued use.

- There are no data to advise continuation or termination of IL-1 blocking therapy if the patient becomes pregnant.

- The efficacy and toxicity of IL-l blocking agents in rheumatic diseases other than RA are unknown although they have been used in juvenile chronic arthritis, adult onset Still's disease, Muckle-Wells syndrome and NOMID (neonatal multi-inflammatory disease). 


\section{Warnings}

- It is possible that there is an increased incidence of infections, including serious infections, when using IL- l blocking agents.

- IL-1 blocking agents should not be started or should be discontinued when serious infections occur.

- Treatment with IL-1 blocking agents should only be resumed if infections have been adequately treated.

\section{Precautionary statement}

- The safety of IL-1 blocking agents is unknown or has not been established in the following situations: lymphoma, lymphoproliferative disease, or other malignancies; pregnancy and/or lactation; in combination with other biologicals, including TNF blocking agents (where great caution ought to be used if these drugs are used together); when using primary vaccinations or live attenuated vaccines.

\section{Appendix 3: Categories of evidence}

Category A evidence: based on evidence from at least one randomised controlled trial or on the meta-analyses of randomised controlled trials.

Category B evidence: based on evidence from at least one controlled trial without randomisation or at least one other type of experimental study or on extrapolated recommendations from randomised controlled trials or meta-analyses.

Category $C$ evidence: based on non-experimental descriptive studies such as comparative studies, correlational studies and case-control studies which are extrapolated from randomised controlled trials, non-randomised controlled studies or other experimental studies.

Category D evidence: based on expert committee reports or opinions or clinical experience of respected authorities or both or extrapolated recommendations from randomised controlled trials, meta-analyses, non-randomised controlled trials, experimental studies, or non-experimental descriptive studies.

Note: Abstracts have not been considered in the above evidence scheme, as they are not complete and may change by the time the data is published, or may not be published as full papers at all. Evidence from abstracts alone, therefore, is considered as category D evidence and noted as "(abstract)" until that data are published as a complete, peer reviewed paper.

\footnotetext{
Authors' affiliations

D E Furst, University of California, UCLA, Rheumatology Division, Los Angeles, CA, USA

F C Breedveld, Department of Rheumatology, Leiden University Medical Centre, Leiden, the Netherlands

J R Kalden, Department of Internal Medicine III, Institut for Clinical Immunology, University of Erlangen-Nuremberg, Erlangen, Germany J S Smolen, Institute of Rheumatology, Clinic for Internal Medicine III, Vienna General Hospital, Vienna, Austria

G R Burmester, Department of Rheumatology, and Clinical Immunology, Charité Hospital, Berlin, Germany

J W J Bijlsma, Department of Rheumatology and Clinical Immunology, University Medical Center, Utrecht, the Netherlands

M Dougados, Institut de Rhumatologie, Hopital Cochin, Paris, France

P Emery, Leeds University, Department of Rheumatology, Leeds General Infirmary, Leeds, UK

E C Keystone, Department of Rheumatology, Mount Sinai Hospitial, Toronto, Canada

L Klareskog, Rheumatology Unit, Department of Medicine, Karolinska Hospital, Stockholm, Sweden
}

P J Mease, Rheumatology Clinical Research, Swedish Hospital Medical Center, Seattle, WA, USA

Correspondence to: Dr D E Furst, 1000 Veteran Avenue Rehabilitation Centre, Room 32-59, Los Angeles, CA 90024, USA; defurst@mednet. ucla.edu

\section{REFERENCES}

1 Furst DE, Breedveld FC, Kalden JR, Smolen JS, Burmester GR, Dougados M, et al. Updated consensus statement on biological agents for the treatment of rheumatoid arthritis and other immune mediated inflammatory diseases (May 2003). Ann Rheum Dis 2003;62(suppl 2):ii2-ii9.

2 Shekelle PG, Woolf SH, Eccles M, Grimshaw J. Clinical guidelines: developing guidelines. BMJ 1999;318:593-6.

3 Wolfe F, Pincus T, O'Dell J. Evaluation and documentation of rheumatoid arthritis disease status in the clinic: which variables best predict change in therapy. J Rheumatol 2001;28:1712-17.

4 Smolen JS, Breedveld FC, Schiff MH, Kalden JR, Emery P, Eberl G, et al. A simplified disease activity index for rheumatoid arthritis for use in clinical practice. Rheumatology (Oxford) 2003;42:244-57.

5 Gladman DD, Helliwell P, Mease PJ, Nash P, Ritchlin C, Taylor W. Assessment of patients with psoriatic arthritis: a review of currently available measures. Arthritis Rheum 2004;50:24-35.

6 Brandt J, Khariouzov A, Listing J, Haibel H, Sorensen H, Grassnickel L, et al. Six-month results of a double-blind, placebo-controlled trial of etanercept treatment in patients with active ankylosing spondylitis. Arthritis Rheum 2003;48:1667-75.

7 Braun J, Brandt J, Listing J, Zink A, Alten R, Golder W, et al. Treatment of active ankylosing spondylitis with infliximab: a randomised controlled multicentre trial. Lancet 2002;359:1 187-93.

8 Davis JC Jr, Van Der HD, Braun J, Dougados M, Cush J, Clegg DO, Kivitz A, et al. Recombinant human tumor necrosis factor receptor (etanercept) for treating ankylosing spondylitis: a randomized, controlled trial. Arthritis Rheum 2003;48:3230-6.

9 Gorman JD, Sack KE, Davis JC Jr. Treatment of ankylosing spondylitis by inhibition of tumor necrosis factor alpha. N Engl J Med 2002;346:1349-56.

10 Van Den BF, Kruithof E, Baeten D, Herssens A, De Keyser F, Mielants H, et al. Randomized double-blind comparison of chimeric monoclonal antibody to tumor necrosis factor alpha (infliximab) versus placebo in active spondylarthropathy. Arthritis Rheum 2002;46:755-65.

11 US Food and Drug Administration. Clinical review. Adalimumab-for use in the treatment of rheumatoid arthritis. Approved 31 December 2003. Available at www.fda.gov/cder/biologics/review/adalabb123102r1.htm (accessed 18 June 2004).

12 Bang LM, Keating GM. Adalimumab: a review of its use in rheumatoid arthritis. BioDrugs 2004; 18:121-39.

13 Bathon JM, Martin RW, Fleischmann RM, Tesser JR, Schiff MH, Keystone EC, et al. A comparison of etanercept and methotrexate in patients with early rheumatoid arthritis. N Engl J Med 2000;343:1586-93.

14 Breedveld FC, Emery P, Keystone E, Patel K, Furst DE, Kalden JR, et al. Infliximab in active early rheumatoid arthritis. Ann Rheum Dis 2004;63: 149-55.

15 Combe B, Condreanu C, Frosco U, et al. Double-blind comparison of etanercept and sulphasalazine alone and combined in patients with active RA [abstract]. Arthritis Rheum 2002;46(suppl):S519.

16 Culy CR, Keating GM. Etanercept: an updated review of its use in rheumatoid arthritis, psoriatic arthritis and juvenile rheumatoid arthritis. Drugs 2002;62:2493-537.

17 Cummins C, Connock M, Fry-Smith A, Burls A. A systematic review of effectiveness and economic evaluation of new drug treatments for juvenile idiopathic arthritis: etanercept. Health Technol Assess 2002;6:1-43.

18 Curran SA, FitzGerald OM, Costello PJ, Selby JM, Kane DJ, Bresnihan B, et al. Nucleotide sequencing of psoriatic arthritis tissue before and during methotrexate administration reveals a complex inflammatory $T$ cell infiltrate with very few clones exhibiting features that suggest they drive the inflammatory process by recognizing autoantigens. J Immunol 2004; 172:1935-44.

19 Elliott MJ, Maini RN, Feldmann M, Long-Fox A, Charles P, Katsikis P, et al. Treatment of rheumatoid arthritis with chimeric monoclonal antibodies to tumor necrosis factor alpha. Arthritis Rheum 1993;36:1681-90.

20 Elliott MJ, Maini RN, Feldmann M, Long-Fox A, Charles P, Bijl H, et al. Repeated therapy with monoclonal antibody to tumour necrosis factor alpha (cA2) in patients with rheumatoid arthritis. Lancet 1994;344:1125-7.

21 Furst DE, Keystone E, Maini RN, Smolen JS. Recapitulation of the round-table discussion-assessing the role of anti-tumour necrosis factor therapy in the treatment of rheumatoid arthritis. Rheumatology (Oxford) 1999;38(suppl 2):50-3.

22 Furst DE, Schiff MH, Fleischmann RM, Strand V, Birbara CA, Compagnone D, et al. Adalimumab, a fully human anti tumor necrosis factor-alpha monoclonal antibody, and concomitant standard antirheumatic therapy for the treatment of rheumatoid arthritis: results of STAR (Safety Trial of Adalimumab in Rheumatoid Arthritis). J Rheumatol 2003;30:2563-71.

23 Garrison L, McDonnell ND. Etanercept: therapeutic use in patients with rheumatoid arthritis. Ann Rheum Dis 1999;58(suppl 1):165-169.

24 Genovese MC, Bathon JM, Martin RW, Fleischmann RM, Tesser JR, Schiff $\mathrm{MH}$, et al. Etanercept versus methotrexate in patients with early rheumatoid arthritis: two-year radiographic and clinical outcomes. Arthritis Rheum 2002;46:1443-50. 
25 Harriman G, Harper LK, Schaible TF. Summary of clinical trials in rheumatoid arthritis using infliximab, an anti-TNFalpha treatment. Ann Rheum Dis 1999;58(suppl 1):161-164.

26 Jarvis B, Faulds D. Etanercept: a review of its use in rheumatoid arthritis. Drugs 1999;57:945-66.

27 Jones RE, Moreland LW. Tumor necrosis factor inhibitors for rheumatoid arthritis. Bull Rheum Dis 1999;48:1-4.

28 Kavanaugh AF. Anti-tumor necrosis factor-alpha monoclonal antibody therapy for rheumatoid arthritis. Rheum Dis Clin North Am 1998;24:593-614

29 Klareskog L, Van Der HD, de Jager JP, Gough A, Kalden J, Malaise M, et al. Therapeutic effect of the combination of etanercept and methotrexate compared with each treatment alone in patients with rheumatoid arthritis: double-blind randomised controlled trial. Lancet 2004;363:675-81.

30 Lipsky PE, van der Heijde DM, St Clair EW, Furst DE, Breedveld FC, Kalden JR, et al. Infliximab and methotrexate in the treatment of rheumatoid arthritis. Anti-Tumor Necrosis Factor Trial in Rheumatoid Arthritis with Concomitant Therapy Study Group. N Engl J Med 2000;343:1594-602.

31 Lovell DJ, Giannini EH, Reiff A, Cawkwell GD, Silverman ED, Nocton JJ, Stein LD, et al. Etanercept in children with polyarticular juvenile rheumatoid arthritis. Pediatric Rheumatology Collaborative Study Group. N Engl J Med 2000;342:763-9.

32 Lovell DJ, Giannini EH, Reiff A, Jones OY, Schneider R, Olson JC, et al. Long term efficacy and safety of etanercept in children with polyarticular-course juvenile rheumatoid arthritis: interim results from an ongoing multicenter, open-label, extended-treatment trial. Arthritis Rheum 2003:48:218-26.

33 Markham A, Lamb HM. Infliximab: a review of its use in the management of rheumatoid arthritis. Drugs 2000;59:1341-59.

34 Moreland LW, Margolies G, Heck LW Jr, Saway A, Blosch C, Hanna R, et al. Recombinant soluble tumor necrosis factor receptor (p80) fusion protein: toxicity and dose finding trial in refractory rheumatoid arthritis. $J$ Rheumatol 1996;23:1849-55.

35 Moreland LW, Schiff MH, Baumgartner SW, Tindall EA, Fleischmann RM, Bulpitt KJ, et al. Etanercept therapy in rheumatoid arthritis. A randomized, controlled trial. Ann Intern Med 1999;130:478-86.

36 Smolen J, Maini R, Keystone E, Bathon JM, Emery P, Kalden J, et al. Treatment of early rheumatoid arthritis with infliximab plus methotrexate or methotrexate alone: preliminary results of the ASPIRE trial. EULAR, 18-21 June, 2003, Lisbon, Portugal (abstract).

37 van de Putte LB, Atkins C, Malaise M, et al. Efficacy and safety of adalimumab as monotherapy in patients with rheumatoid arthritis who have failed previous disease-modifying antirheumatic drug therapy. Ann Rheum Dis 2004; (in press)

38 St Clair EW, van der Heijde DM, Smolen JS, Maini RN, Bathon JM, Emery P, et al. Active-controlled study of patients receiving infliximab for the Treatment of Rheumatoid Arthritis of Early Onset Study Group. Combination of Infliximab and Methotrexate therapy for early rheumatoid arthritis. Arthritis Rheum 2004; (in press).

39 Maini RN, Breedveld FC, Kalden JR, Smolen JS, Davis D, Macfarlane JD, et al. Therapeutic efficacy of multiple intravenous infusions of anti-tumor necrosis factor alpha monoclonal antibody combined with low-dose weekly methotrexate in rheumatoid arthritis. Arthritis Rheum 1998;41:1552-63.

40 Antoni C, Dechant C, Hanns-Martin Lorenz PD, Wendler J, Ogilvie A, et al. Open-label study of infliximab treatment for psoriatic arthritis: clinical and magnetic resonance imaging measurements of reduction of inflammation. Arthritis Rheum 2002;47:506-12.

41 Cauza E, Spak M, Cauza K, Hanusch-Enserer U, Dunky A, Wagner E. Treatment of psoriatic arthritis and psoriasis vulgaris with the tumor necrosis factor inhibitor infliximab. Rheumatol Int 2002:22:227-32.

42 Feletar M, Brockbank JE, Schentag CT, Lapp V, Gladman DD. Treatment of refractory psoriatic arthritis with infliximab: a 12 month observational study of 16 patients. Ann Rheum Dis 2004;63:156-61.

43 Mease PJ, Goffe BS, Metz J, Van der Stoep A, Finck B, Burge DJ. Etanercept in the treatment of psoriatic arthritis and psoriasis: a randomised trial. Lancet 2000;356:385-90.

44 Mease PJ, Kivitz AJ, Burch FX, Siegel EL, Cohen SB, Ory P, Salonen D, et al. Etanercept treatment of psoriatic arthritis: Safety, efficacy, and effect on disease progression. Arthritis Rheum 2004:50:2264-72.

45 Ogilvie AL, Antoni C, Dechant C, Manger B, Kalden JR, Schuler G, et al. Treatment of psoriatic arthritis with antitumour necrosis factor-alpha antibody clears skin lesions of psoriasis resistant to treatment with methotrexate. Br J Dermatol 2001;144:587-9.

46 Salvarani C, Cantini F, Olivieri I, Macchioni P, Padula A, Niccoli L, et al. Efficacy of infliximab in resistant psoriatic arthritis. Arthritis Rheum 2003;49:541-5

47 Scheinfeld N. Adalimumab (HUMIRA): a review. J Drugs Dermatol 2003:2:375-7

48 Clegg DO, Reda DJ, Mejias E, Cannon GW, Weisman MH, Taylor T, et al. Comparison of sulfasalazine and placebo in the treatment of psoriatic arthritis. A Department of Veterans Affairs Cooperative Study. Arthritis Rheum 1996;39:2013-20.

49 Dougados $M$, vam der LS, Leirisalo-Repo M, Huiffeldt B, Juhlin R, Veys $E$, et al. Sulfasalazine in the treatment of spondylarthropathy. A randomized, multicenter, double-blind, placebo-controlled study. Arthritis Rheum 1995;38:618-27.

50 Goupille P, Valat JP. Sulfasalazine: a definitively efficient treatment for psoriatic arthritis. J Rheumatol 1996:23:791-2.

51 Spadaro A, Riccieri V, Sili-Scavalli A, Sensi F, Taccari E, Zoppini A Comparison of cyclosporin $A$ and methotrexate in the treatment of psoriatic arthritis: a one-year prospective study. Clin Exp Rheumato 1995; 13:589-93.
52 Willkens RF, Williams HJ, Ward JR, Egger MJ, Reading JC, Clements PJ, et al. Randomized, double-blind, placebo controlled trial of low-dose pulse methotrexate in psoriatic arthritis. Arthritis Rheum 1984;27:376-81.

53 Mease PJ. Etanercept, a TNF antagonist for treatment for psoriatic arthritis and psoriasis. Skin Therapy Lett 2003;8:1-4

54 Menter A, Evans R, Dooley L, et al. Infliximab improves signs of plaque psoriasis in patients with psoriatic arthritis. Annual Scientific Meeting American College of Rheumatology, 25-27 October 2003, Orlando, USA, (abstract no 331).

55 Tutrone WD, Saini R, Weinberg JM. Biological therapy for psoriasis: an overview of infliximab, etanercept, efalizumab and alefacept. IDrugs 2004:7:45-9

56 Chaudhari U, Romano P, Mulcahy LD, Dooley LT, Baker DG, Gottlieb AB. Efficacy and safety of infliximab monotherapy for plaque-type psoriasis: a randomised trial. Lancet 2001;357:1842-7.

57 Gottlieb AB, Chaudhari U, Mulcahy LD, Li S, Dooley LT, Baker DG. Infliximab monotherapy provides rapid and sustained benefit for plaque-type psoriasis. J Am Acad Dermatol 2003;48:829-35.

58 Leonardi CL, Powers JL, Matheson RT, Goffe BS, Zitnik R, Wang A, et al. Etanercept as monotherapy in patients with psoriasis. N Engl J Med 2003:349:2014-22.

59 Davis J Jr, Webb A, Lund S, Sack K. Results from an open-label extension study of etanercept in ankylosing spondylitis. Arthritis Rheum 2004;51:302-4

60 Brandt J, Haibel H, Reddig J, et al. Anti-TNF alpha treatment of patients with severe anklyosing spondylitis-a one year follow-up [abstract]. Arthritis Rheum 2000;44(suppl):S403.

61 Brandt J, Kavenaugh AF, Listing J, et al. Six months results of a German double-blind placebo controlled Phase III clinical trial in active ankylosing spondylitis [abstract]. Arthritis Rheum 2002;46:S429.

62 Baeten D, Demetter P, Kruithof E, et al. Effect of TNF alpha blockade on synovial histology in spondyloarthropathy [abstract]. Arthritis Rheum 2000;43(suppl):S4040.

63 Baeten D, Kruithof E, Van Den BF, Van den BN, Herssens A, Mielants H, et al. Systematic safety follow up in a cohort of 107 patients with spondyloarthropathy treated with infliximab: a new perspective on the role of host defence in the pathogenesis of the disease? Ann Rheum Dis 2003;62:829-34

64 Braun J, Pham T, Sieper J, Davis J, van der LS, Dougados M, Van Der HD. International ASAS consensus statement for the use of anti-tumour necrosis factor agents in patients with ankylosing spondylitis. Ann Rheum Dis 2003;62:817-24.

65 Kavanaugh AF, Han C, Bala M. Functional status and radiographic joint damage are associated with health and economic outcomes in patients with RA. J Rheumatol 2004;31:849-55.

66 Chiou C, Wanke L, Yu E, et al. A cost-effectiveness analysis of biological treatments for rheumatoid arthritis [abstract]. ISPOR 2004;7631:AR2

67 Bansback N, Brennan A, Conway P, Reynolds A. Impact of direct and indirect costs on the cost-effectiveness of etanercept in rheumatoid arthritis in the UK. Annual European Congress of Rheumatology EULAR 2002, Stockholm, Sweden, 12-15 June, 2002.

68 Chaudhari U, Romano P, Mulcahy LD, Dooley LT, Baker DG, Gottlieb AB. Efficacy and safety of infliximab monotherapy for plaque-type psoriasis: a randomised trial. Lancet 2001;357:1842-7.

69 Hanquer SB, Feagan BG, Lichtenstein GR, Mayer LF, Schreiber S, Colombel JF, et al. Maintenance infliximab for Crohn's disease: the ACCENT I randomised trial. Lancet 2002;359:1541-9.

70 Baert F, Noman M, Vermeire S, Van Assche G, D' Haens G, Carbonez A, et al. Influence of immunogenicity on the long-term efficacy of infliximab in Crohn's disease. N Engl J Med 2003;348:601-8.

71 Steinfeld SD, Demols P, Salmon I, Kiss R, Appelboom T. Infliximab in patients with primary Sjögren's syndrome: a pilot study. Arthritis Rheum 2001;44:2371-5.

72 Mariette X, Ravaud P, Steinfeld S, Baron G, Goetz J, Hachulla E, et al. Inefficacy of infliximab in primary Sjogren's syndrome: results of the randomized, controlled Trial of Remicade in Primary Sjogren's Syndrome (TRIPSS). Arthritis Rheum 2004;50:1270-6.

73 Sankar V, Brennan MT, Kok MR, Leakan RA, Smith JA, Manny J, et al. Etanercept in Sjogren's syndrome: a twelve-week randomized, double-blind, placebo-controlled pilot clinical trial. Arthritis Rheum 2004;50:2240-5.

74 Gause AM, Arbach O, Reinhold-Keller E, et al. Induction of remission with infliximab in active generalized Wegener's granulomatosis is effective but complicated by severe infections. Annual Scientific Meeting, American College of Rheumatology, 25-27 October 2003, Orlando, USA, (abstract no 450).

75 Stone JH, Uhlfelder ML, Hellmann DB. Etanercept in Wegener's granulomatosis: results of an open-label trial. Annual Scientific Meeting, American College of Rheumatology, November 1999, Boston, MA, USA, (abstract no 1467).

76 Huffstutter J, Sienknechet C. Resistant adult Still's disease treated with infliximab-a report of two cases [abstract]. Arthritis Rheum 2002;46(suppl):S326

77 Kraetsch HG, Antoni C, Kalden JR, Manger B. Successful treatment of a small cohort of patients with adult onset of Still's disease with infliximab: first experiences. Ann Rheum Dis 2001;60(suppl 3):iii55-iii57.

78 Weinblatt ME, Maier AL, Mease PJ, Overman SS, Fraser P, Gravallese EM. Etanercept in the treatment of adult patients with Still's disease. Arthritis Rheum 2002;46:1171-6.

79 Elkayam O, Hawkins PN, Lachmann H, Yaron M, Caspi D. Rapid and complete resolution of proteinuria due to renal amyloidosis in a patient with 
rheumatoid arthritis treated with infliximab. Arthritis Rheum 2002;46:2571-3.

80 Gottenberg JE, Merle-Vincent F, Bentaberry F, Allanore Y, Berenbaum F, Fautrel $B$, et al. Anti-tumor necrosis factor alpha therapy in fifteen patients with $\mathrm{AA}$ amyloidosis secondary to inflammatory arthritides: a follow up report of tolerability and efficacy. Arthritis Rheum 2003;48:2019-24.

81 Ortiz-Santamaria V, Vals-Roc M, Sanmarti M, et al. Treatment of secondary amyloidosis with infliximab [abstract]. Arthritis Rheum 2002;46(suppl):S71.

82 Tomero E, Carmona L, Gonzalez I, et al. Infliximab in secondary amyloidosis complicating inflammatory arthropathies [abstract]. Arthritis Rheum 2002;46(suppl):S70.

83 Estrach C, Mpofu S, Moots RJ. Efficacy and safety of infliximab and adalimumab in Behcet's syndrome. Annual Scientific Meeting, American College of Rheumatology, 25-27 October 2003, Orlando, USA, labstract no 1125).

84 Gulli S, Arrigo C, Bocchino L, Morgante L, Sangari D, Castagna I, et al. Remission of Behcet's disease with anti-tumor necrosis factor monoclonal antibody therapy: a case report. BMC Musculoskelet Disord 2003;4:19.

85 Hassard PV, Binder SW, Nelson V, Vasiliauskas EA. Anti-tumor necrosis factor monoclonal antibody therapy for gastrointestinal Behcet's disease: a case report. Gastroenterology 2001;120:995-9.

86 Licata G, Pinto A, Tuttolomondo A, Banco A, Ciccia F, Ferrante A, et al. Antitumour necrosis factor alpha monoclonal antibody therapy for recalcitrant cerebral vasculitis in a patient with Behcet's syndrome. Ann Rheum Dis 2003:62:280-1.

87 Melikoghu M, Fresko I, Mat C, et al. Etanercept is beneficial in controlling the mucocutaneous lesions of Bechet's syndrome [abstract]. Arthritis Rheum 2002;46(suppl):S206

88 Rozenbaum M, Rosner I, Portnoy E. Remission of Behcet's syndrome with TNFalpha blocking treatment. Ann Rheum Dis 2002;61:283-4.

89 Saulsbury FT, Mann JA. Treatment with infliximab for a child with Behcet's disease. Arthritis Rheum 2003;49:599-600

90 Sfikakis PP, Theodossiadis PG, Katsiari CG, Kaklamanis P, Markomichelakis NN. Effect of infliximab on sight-threatening panuveitis in Behcet's disease. Lancet 2001;358:295-6.

91 Sfikakis PP. Behcet's disease: a new target for anti-tumour necrosis factor treatment. Ann Rheum Dis 2002;61(suppl 2):ii51-ii53.

92 Shereen F, Moore TL. Successful resolution of mucocutaneous ulcers in Behcet's disease with use of infliximab-a case series. Annual Scientific Meeting, American College of Rheumatology, 25-27 October 2003, Orlando, USA, (abstract no 1619).

93 Fietchner J. Treatment of primary biliary cirrhosis with Remicade (infliximab) Arthritis Rheum 2003;48(suppl).

94 Naveau S, Chollet-Martin S, Dharancy S, Mathurin P, Jouet P, Piquet MA, et al. A double-blind randomized controlled trial of infliximab associated with prednisolone in acute alcoholic hepatitis. Hepatology 2004;39:1390-7.

95 Spahr L, Rubbia-Brandt L, Frossard JL, Giostra E, Rougemont AL, Pugin J et al. Combination of steroids with infliximab or placebo in severe alcoholic hepatitis: a randomized controlled pilot study. J Hepatol 2002;37:448-55.

96 Hengstman G, van den Hoogen F, ven Engelen B, et al. Anti-TNF blockade with infliximab (Remicade) in polymyositis and dermatomyositis [abstract]. Arthritis Rheum 2000;43(suppl):S193.

97 Miller M, Mendez E, Klein-Gitelman M, Pachman L. Use of etanercept in juvenile dermatomyositis [abstract]. Arthritis Rheum 2002;46(suppl):S306.

98 Saadeh C. Etanercept is effective in the treatment of polymyositis/ dermatomyositis which is refractory to conventional therapy [abstract] Arthritis Rheum 2000;43(suppl):S193.

99 Nzeusseu A, Durez P, Houssiau F. Successful use of infliximab in a case of refractory juvenile dermatomyositis. Arthritis Rheum 2001;44(suppl):S90.

100 Hull KM, Drewe E, Aksentijevich I, Singh HK, Wong K, McDermott EM, et al. The TNF receptor-associated periodic syndrome (TRAPS): emerging concepts of an autoinflammatory disorder. Medicine (Baltimore) 2002;81:349-68.

101 Takada K, Aksentijevich I, Mahadevan V, Dean JA, Kelley RI, Kastner DL. Favorable preliminary experience with etanercept in two patients with the hyperimmunoglobulinemia $D$ and periodic fever syndrome. Arthritis Rheum 2003;48:2645-51

102 Andonopoulos AP, Meimaris N, Daoussis D, Bounas A, Giannopoulos G. Experience with infliximab (anti-TNF alpha monoclonal antibody) as monotherapy for giant cell arteritis. Ann Rheum Dis 2003;62:1116.

103 Cantini F, Niccoli L, Salvarani C, Padula A, Olivieri I. Treatment of longstanding active giant cell arteritis with infliximab: report of four cases. Arthritis Rheum 2001;44:2933-5.

104 Tan AL, Holdsworth J, Pease C, Emery P, McGonagle D. Successful treatment of resistant giant cell arteritis with etanercept. Ann Rheum Dis 2003;62:373-4

105 Cacoub P, Lidove O, Maisonobe T, Duhaut P, Thibault V, Ghillani P, et al. Interferon-alpha and ribavirin treatment in patients with hepatitis $C$ virusrelated systemic vasculitis. Arthritis Rheum 2002:46:3317-26.

106 McMinn JR Jr, Cohen S, Moore J, Lilly S, Parkhurst J, Tarantino MD, et al. Complete recovery from refractory immune thrombocytopenic purpura in three patients treated with etanercept. Am J Hematol 2003;73:135-40.

107 Peterson JR, Hsu FC, Simkin PA, Wener MH. Effect of tumour necrosis facto alpha antagonists on serum transaminases and viraemia in patients with rheumatoid arthritis and chronic hepatitis $C$ infection. Ann Rheum Dis 2003;62:1078-82.

108 Pritchard C. Etanercept and Hepatitis C. J Clin Rheum 1999:5:179.

109 Weiss JE, Eberhard BA, Chowdhury D, Gottlieb BS. Infliximab as a novel therapy for refractory Kawasaki disease. J Rheumatol 2004;31:808-10.

110 Calamia K, Walsh JS, Kovach B, Ginsburg WW. Treatment of multicentric reticulohistocytosis with etanercept: a case report. Annual Scientific Meeting
American College of Rheumatology, 25-27 October 2003, Orlando, USA, (abstract no 16808)

111 Birnbaum AJ, Gentile P. Treatment of myelodysplasia in a patient with active rheumatoid arthritis. Ann Intern Med 2000;133:753-4.

112 Athreya B, Doughty R, Kastner D, et al. Periodic fever syndrome in children [abstract]. Arthritis Rheum 2000;43(suppl):S117.

113 Ehresman G. Infliximab in the treatment of polychondritis [abstract]. Arthritis Rheum 2002;46(suppl):S170.

114 Anker SD, Coats AJ. How to RECOVER from RENAISSANCE? The significance of the results of RECOVER, RENAISSANCE, RENEWAL and ATTACH. Int J Cardiol 2002;86:123-30.

115 Khanna D, Liebling MR, Lovie JS. Etanercept ameliorates sarcoidosis arthritis and skin disease. J Rheumatol 2003;30:1864-7.

116 Khanna D, Liebling MR, Lovie JS. Treatment of resistant sarcoid arthropathy with etanercept. J Rheumatol 2004; (in press).

117 Sweiss N, Ellman N, Curran J, Utset T, et al. TNF-inhibitor as novel treatment for refractory sarcoidosis [abstract]. Arthritis Rheum 2002;46(suppl):S324.

118 Sweiss N, Curran J, Ellman N. TNF-inhibition as a novel treatment for refractory sarcoidosis. Annual Scientific Meeting, American College of Rheumatology, 25-27 October 2003, Orlando, USA, (abstract no 1605).

119 Utz JP, Limper AH, Kalra S, Specks U, Scott JP, Vuk-Pavlovic Z, et al. Etanercept for the treatment of stage II and III progressive pulmonary sarcoidosis. Chest 2003; 124:177-85.

120 Ellman MH, MacDonald PA, Hayes FA. Etanercept treatment for diffuse scleroderma: a pilot study [abstract]. Arthritis Rheum 2000;43(suppl):S392

121 Hernandez-Ibarra H, Gutierrez L, Juarez S, et al. Prevalence, burden of illness and factors associated with neurocognitive dysfunction in Mexican patients with systemic lupus erythematous. Annual Scientific Meeting, American College of Rheumatology, 25-27 October 2003, Orlando, USA, (abstract no 378).

122 Hoffman GS, Merkel PA, Brasington RD, Lenschow DJ, Liang P. Anti-tumor necrosis factor therapy in patients with difficult to treat Takayasu arteritis. Arthritis Rheum 2004;50:2296-304.

123 Joseph A, Raj D, Dua HS, Powell PT, Lanyon PC, Powell RJ. Infliximab in the treatment of refractory posterior uveitis. Ophthalmology 2003:110:1449-53.

124 Suhler E, Smith J, Kurz D, et al. A prospective trial of infliximab therapy for patients with refractory uveitis: preliminary results. Annual Scientific Meeting, American College of Rheumatology, 25-27 October 2003, Orlando, USA, (abstract no 1102).

125 Booth A, Harper L, Hammad T, Bacon P, Griffith M, Levy J, et al. Prospective study of TNFalpha blockade with infliximab in anti-neutrophil cytoplasmic antibody-associated systemic vasculitis. J Am Soc Nephrol 2004;15:717-21.

126 Burmester GR, van de Putte LB, Rau P, et al. Long term efficacy and safety of adalimumab monotherapy in patients with DMARD-refractory RA-results from a two year study. Arthritis Rheum 2002;46:S537

127 Mangge H, Heinzl B, Grubbaver HM, El Shabrawi Y, Schauenstein K. Therapeutic experience with infliximab in a patient with polyarticular juvenile idiopathic arthritis and uveitis. Rheumatol Int 2003;23:258-61.

128 Brocq O, Plubel Y, Breuil V, Grisot C, Flory P, Mousnier A, et al. Etanerceptinfliximab switch in rheumatoid arthritis 14 out of 131 patients treated with anti TNF $\alpha$. Presse Med 2002;31:1836-9.

129 Buch MH, Bingham SJ, Rees-Evans B, et al. Do patients with rheumatoid arthritis with high disease activity on infliximab demonstrate improvement on etanercept? BSR Annual Meeting [abstract]. Rheumatology 2003:42: (abstract no 221).

130 Hochberg MC, Tracy JK, Hawkins-Holt M, Flores RH. Comparison of the efficacy of the tumour necrosis factor alpha blocking agents adalimumab, etanercept, and infliximab when added to methotrexate in patients with active rheumatoid arthritis. Ann Rheum Dis 2003:62(suppl 2):ii13-iil6.

131 Maksymowych WP, Mallon C, Spady B, Peerani R. Alberta Capital Health region studies in rheumatoid arthritis prospective observational inception cohort: efficacy, adverse events and withdrawal [abstract]. Arthritis Rheum 2001;44(suppl):S82.

132 Shergy WJ, Phillips RM Jr, Hunt RE, Hernandez J. Safety and efficacy of infliximab therapy after etanercept failure: a case series [abstract]. Arthritis Rheum 2001;44(suppl):S81.

133 van Vollenhoven RF, Brannemark S, Klareskog L. Dose escalation of infliximab in clinical practice: improvements seen may be explained by a regression-like effect. Ann Rheum Dis 2004;63:426-30.

134 Keystone E, Kavanaugh AF, Sharp JT, et al. Adalimumab, a fully human anti-TNF-alpha monoclonal antibody, inhibits the progression of structural joint damage in patients with active RA despite concomitant methotrexate therapy [abstract]. Arthritis Rheum 2002;46(suppl):S205

135 Smolen JS, Han C, Bala M, Maini R, Kalden J, van der Heijde DM, et al. Evidence of radiographic benefit of infliximab plus methotrexate in rheumatoid arthritis patients who had no clinical improvement. A detailed subanalysis of the ATTRACT trial. Arthritis Rheum 2004; (in press).

136 Wallis RS, Broder MS, Wong JY, Hanson ME, Beenhouwer DO. Granulomatous infectious diseases associated with tumor necrosis factor antagonists. Clin Infect Dis 2004;38:1261-5

137 Keane J, Gershon S, Wise RP, Mirabile-Levens E, Kasznica J, Schwieterman WD, et al. Tuberculosis associated with infliximab, a tumor necrosis factor alpha-neutralizing agent. N Engl J Med 2001;345: 1098-104.

138 Schiff $M$, van der Putter LB, Breedveld FC, Kupper H, Fischkoff S, et al. Rates of infection in adalimumab rheumatoid arthritis clinical trials. Ann Rheum Dis 2003;62(suppl 1): (abstract no 184). 
139 Furst $D E$, Wallis $R$, Beenhouwer $D$, et al. Tumour necrosis factor antagonists and granulomatous infections: mechanisms of action. Semin Arthritis Rheum 2004; (in press).

140 Singh G, Ramey D, Rausch PL, Schettler J. Serious infections in rheumatoid arthritis: Relationship to immunosuppressive use [abstract]. Arthritis Rheum 1999;42(suppl):S242.

141 Doran MF, Crowson CS, Pond GR, O'Fallon WM, Gabriel SE. Predictors of infection in rheumatoid arthritis. Arthritis Rheum 2002;46:2294-300.

142 Doran MF, Crowson CS, Pond GR, O'Fallon WM, Gabriel SE. Frequency of infection in patients with rheumatoid arthritis compared with controls: a population-based study. Arthritis Rheum 2002;46:2287-93.

143 Elkayam O, Caspi D, Reitblatt T, Charboneau D, Rubins JB. The effect of tumor necrosis factor blockade on the response to pneumococcal vaccination in patients with rheumatoid arthritis and ankylosing spondylitis. Semin Arthritis Rheum 2004;33:283-8.

144 Slifman NR, Gershon SK, Lee JH, Edwards ET, Braun MM. Listeria monocytogenes infection as a complication of treatment with tumor necrosis factor alpha-neutralizing agents. Arthritis Rheum 2003;48:319-24.

145 Hanaver SB. Review article: safety of infliximab in clinical trials. Aliment Pharmacol Ther 1999;13(suppl 4):16-22.

146 Baeten D, De Keyser F, Kruithof E, et al. Systematic review of the serious and atypical infections in spondyloarthropathy patients treated with anti-TNFx [abstract]. Arthritis Rheum 2002;46(suppl):S432.

147 Bargstrom L, Yocum D, Tesser J, et al. Coccidiomycosis (Valley Fever) occurring during infliximab therapy [abstract]. Arthritis Rheum 2004;46:(abstract no 5169).

148 Khanna D, McMahon M, Furst DE. Safety of tumour necrosis factor-alpha antagonists. Drug Saf 2004;27:307-24.

149 Lee JH, Slifman NR, Gershon SK, Edwards ET, Schwieterman WD, Siegel JN, et al. Life-threatening histoplasmosis complicating immunotherapy with tumor necrosis factor alpha antagonists infliximab and etanercept. Arthritis Rheum 2002;46:2565-70.

150 Manadan AM, Block JA, Sequeira W. Mycobacteria tuberculosis peritonitis associated with etanercept therapy. Clin Exp Rheumatol 2003;21:526.

151 Zhao S, Makuch RW, Wentworth C, et al. Incidence rates of tuberculosis in patients with rheumatoid arthritis or ankylosing spondylitis in comparison with the general population. J Rheumatol 2004; (in press).

152 Baecklund E, Ekbom A, Sparen P, Feltelius N, Klareskog L. Disease activity and risk of lymphoma in patients with rheumatoid arthritis: nested casecontrol study. BMJ 1998;317:180-1
153 Prior P, Symmons DP, Hawkins CF, Scott DL, Brown R. Cancer morbidity in rheumatoid arthritis. Ann Rheum Dis 1984;43:128-31.

154 Cush J, Spiera R. Etanercept update on "dear doctor" safety letter. ACR Hotline 12 May 2002.

155 Kwon HJ, Cote TR, Cuffe MS, Kramer JM, Braun MM. Case reports of heart failure after therapy with a tumor necrosis factor antagonist. Ann Intern Med 2003; 138:807-11

156 Khanna M, Shirodkar MA, Gottlieb AB. Etanercept therapy in patients with autoimmunity and hepatitis C. J Dermatolog Treat 2003;14:229-32.

157 Schiemann U, Kellner H. [Gastrointestinal side effects in the therapy of rheumatologic diseases]. Z Gastroenterol 2002;40:937-43.

158 Antoni CE, Furst DE, Manger B, Lichtenstein GR, et al. Outcome of pregnancy in women receiving infliximab for the treatment of Crohn's disease or rheumatoid arthritis [abstract]. Arthritis Rheum 2001;44(suppl):S152.

159 Bingham SJ, Barcelos A, Buch M, et al. Induction of serological lupus in patients on leflunomide and infliximab [abstract]. Arthritis Rheum 2002;46(suppl):S168.

160 Christopher L, Wigley F. TNF-alpha antagonists induce lupus-like syndrome in patients scleroderma and polyarthritis [abstract]. Arthritis Rheum 2002;46(suppl):S358.

161 De Rycke L, Kruithof E, Van Damme N, Hoffman IE, Van den BN, Van Den $\mathrm{BF}$, et al. Antinuclear antibodies following infliximab treatment in patients with rheumatoid arthritis or spondylarthropathy. Arthritis Rheum 2003;48:1015-23

162 Wagner C, St Clair EW, Han C, et al. Effects of antibodies to infliximab on ACR response in patients with RA in the ATTRACT Study. Arthritis Rheum 2002;46:S132.

163 Ruderman EM, Markenson JA. Granulomatous infections and tumor necrosis factor antagonist therapies: update through June 2002. Arthritis Rheum 2003:48(suppl 9).

164 Mohan N, Edwards ET, Cupps TR, Oliverio PJ, Sandberg G, Crayton H Richert JR, Siegel JN. Demyelination occurring during anti-tumor necrosis factor alpha therapy for inflammatory arthritides. Arthritis Rheum $2001 ; 44: 2862-9$.

165 Whiting-O'Keefe QE, Fye KH, Sack KD. Methotrexate and histologic hepatic abnormalities: a meta-analysis. Am J Med 1991:90:711-16.

166 Haraoui B, Barrelle D, Kaminska E. Anakinra in the treatment of adult onset Still's disease. EULAR, 9-12 June 2004, Berlin, Germany, 2004 (abstract no 148) 